\title{
Biometric study of the deep bodied mahseer Tor tor (Hamilton Buchanan) from Ujh River, Kathua (J\&K).
}

\author{
Monika Bansal ${ }^{1} \cdot$ Ankush Sharma ${ }^{1} \cdot \operatorname{Ram~Krishan}^{* 2} \cdot$ Rajesh Kumar $^{3} \cdot \operatorname{Koshal~Kumar}^{4} \bullet$ Smita $^{2}$ \\ Badola $^{5}$ \\ ${ }^{1}$ Department of Zoology, Sri Sai University, Palampur, (H.P) \\ ${ }^{2}$ Department of Zoology, Govt. Degree College, Kathua (J\&K) \\ ${ }^{3}$ Department of Zoology, Himachal Pradesh University, Shimla (H.P) \\ ${ }^{4}$ Department of Zoology, HNB Garhwal University BGR Campus, Pauri Garhwal, Uttarakhand \\ ${ }^{5}$ Department of Zoology, SDS University Campus, Rishikesh, Uttarakhand \\ *Corresponding author: rkjarngal@gmail.com
}

Received: 27.9.2021; Revised: 27.11.2021; Accepted: 29.11.2021

CSociety for Himalayan Action Research and Development

\begin{abstract}
Morphometric characters and meristic count of a fish, Tor tor (Hamilton Buchanan) have been studied from river Ujh, a tributary of river Ravi in District Kathua, (J\&K). Collection of samples on monthly basis was conducted for the study of morphological characters of Tor tor. Present study shows some deviations with respect to few morphometric characters and meristic counts that have been aptly discussed in the following discussion. The positive correlation has been observed between total length and external body parts. The highly strong correlated body parameter in relation to total length is standard length $(\mathrm{r}=0.98)$ and least correlated with eye diameter $(\mathrm{r}=0.32)$ and the highly correlated external body part in relation to standard length is caudal length $(r=0.96)$ and least correlated part is eye diameter $(r=0.35)$ and also strong correlation was observed between head length and maximum body depth $(r=0.93)$ and least correlation between head length and eye diameter $(\mathrm{r}=0.23)$. The correlation analysis shows that all the morphometric characters change proportionally with increase in the total length. These results act as baseline data on morphometry of Tor tor which helps in easy identification and will be beneficial for the development of conservational strategies of the natural stocks of Tor tor in river Ujh, Kathua (J\&K).
\end{abstract}

Key words: Tor tor, Morphometric analysis, Meristic analysis, morphometric board, needle.

\section{Introduction:}

The huge water spread area and geophysical conditions of Jammu and Kashmir provide a great scope for a number of fish species to develop in natural as well as controlled condition. In both the division of the Union Territory viz., Jammu and Kashmir, we find fish and fisheries activities distinct to geophysical conditions, cold water fishes largely abound in Kashmir and the warm water fish and fisheries are dominant in Jammu. Taxonomy is all-important for the efficacious identification and management of fishery. Identification of the species plays a key role for the study of fish biology. Identification of fish is based on inter-relationship of morphometric, meristic and some descriptive characters. According to Nikolski (1961), the species is characterised by relatively high morphological stability, the results of adaptation to particular environment within which it formed, developed and lived. The characteristics of species represent its adaptation to given set of environmental conditions. The species presents its particular niche, within the limits of which living conditions are adequate and in accordance within its morphological peculiarities.

The Mahseer (Tor tor) is the elegant sport fish known as the "tiger of water peril". Mahseer 
(Tor tor) is the most important game fish found all along the Himalayan region. In India it is found in Assam, Bihar, Uttar Pradesh, Uttaranchal, West Bengal, Nagaland, Himachal Pradesh and Jammu \& Kashmir. Mahseer (Tor tor) is the most commercial fish of Jammu \& Kashmir. The population of this fish has been declining because of overfishing, habitat loss, introduction of exotic species and human modification to the environment (Joshi et al., 1994). Mahseer (Tor tor) is the major fish having a great socio-economic role but in recent years, it has come under threatened category of fish and are now become endangered due to changing weather conditions, construction of dams act as physical barriers to this migratory species tending to prevent their access to their usual breeding and feeding grounds and high degree of toxic pollutants filling in the rivers of Jammu like Tawi, Basantar and Ujh. Though, Tor tor is typical hill stream fish and plays an important role to maintain the ecological balance of hill streams, hence study on its conservation and management is very essential. In fishes, the first step towards their conservation is accurate measurements and counts of fin rays elements. Morphometric and Meristic study are important tool for measuring discreteness of the same species. The importance of morphometric also been proved in the study of sexual dimorphism. The present work will be significant to give information to fishery biologist about morphometric and meristic characters of the fish Tor tor from river Ujh, Kathua district of Jammu and Kashmir. This will help to plan further conservation strategy for this fish.

Study Area: A tributary of river Ravi near Jasrota village having 32.4728 N, 75.4174 E Ujh river originates in Kailash Mountains near Bhaderwah hills, parts of Pir Panjal Range at an altitude of $4300 \mathrm{~m}(14,100 \mathrm{ft}$.). It flows a distance of nearly $100 \mathrm{Km}$ some of it in Pakistani Punjab (Fig 1) before joining river near Chak Ram sahai in Indian Punjab (Jain $e t$ al., 2007).

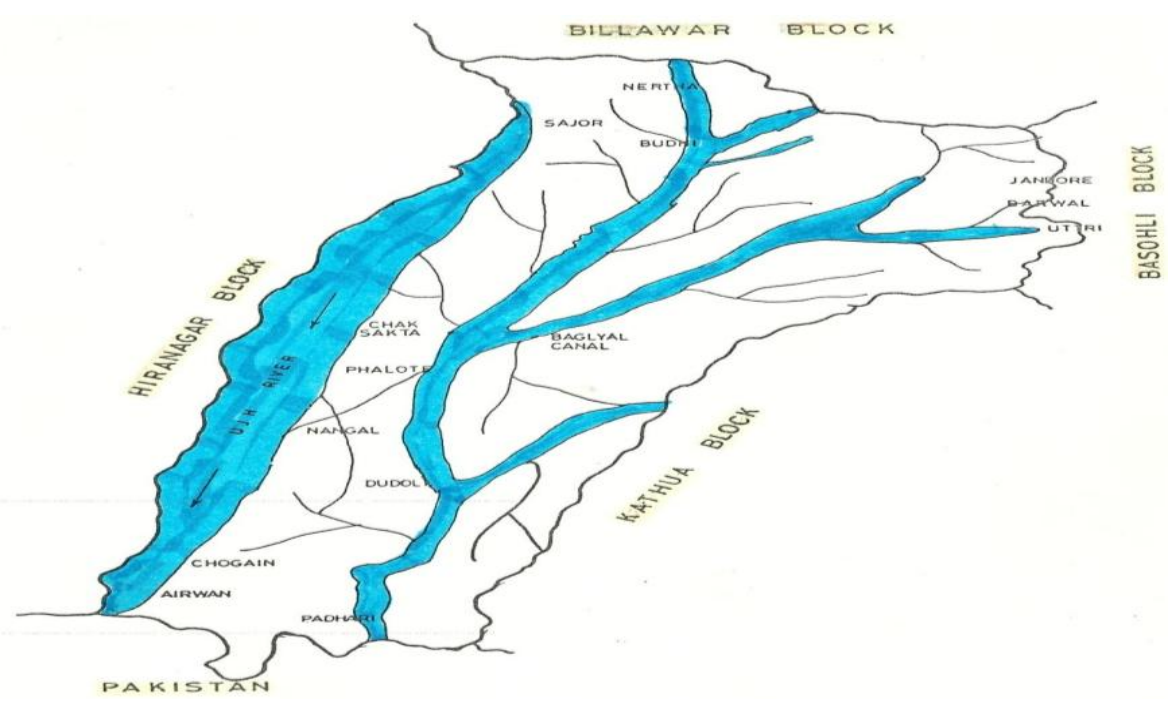

Fig. 1: Geographical representation of Ujh River in Kathua District 


\section{Material and Methods:}

A total number of 30 specimens of Tor tor (Mahseer) were collected from river Ujh, Kathua district of Jammu and Kashmir with the help of standard fishing gears from January(2020) to June (2020). The specimen were preserved in $10 \%$ formalin solution on the spot and were brought to the laboratory for further analysis. The meristic counts and morphometric measurements were recorded.

Morphometric Study: For morphometric studies, the parameters considered were the total length, standard length, head length, predorsal length, pre-ventral length, pre-anal length, caudal length, snout length, eye diameter and maximum body depth. These (pre-dorsal length, pre-ventral length, pre-anal length, caudal length, snout length, eye diameter and maximum body depth) variables were studied in relation to total length, standard length and head length separately as per taxonomy requirement. Fish measurement board and sharp pointed needle like dividers were used for taking body measurements.

Meristic Study: Meristic counts are countable characters like fin rays and fin spines etc. were also studied with the help of fine forceps and hand lens.

\section{Regression Analysis:}

The original data were grouped into class intervals and the average value for the dependent $(\mathrm{Y})$ and independent variables(X) were calculated.
Where $\mathrm{Y}$ is the dependent variables character like Standard length, Head length. $\mathrm{X}$ is the independent variables like Total length.

$\mathrm{a}$ is the intercept.

$\mathrm{b}$ is the regression coefficient.

These values then fed into an electronic calculator for computing the value of correlation coefficient (r) and the regression coefficient (b) along with intercept (a). The relationship determined by filling into the following straightline equation. The relationship is determined by fitting into the following straight line equation:

$\mathrm{Y}=\mathrm{a}+\mathrm{b} \cdot \mathrm{X}$

\section{Observations}

For morphometric and meristic analysis 30 specimens of Tor tor were used in different size groups. Body is stout, elongated and compressed. The ventral profile is more arched than dorsal profile. Head is comparatively smaller than maximum body depth. Mouth is small and inferior with two pairs of barbles. Eyes are visible from below the head. Lips are thick and fleshy, running at angles of mouth. Large scales are present on the body. Scaly sheath present on the base of the dorsal and the last unbranched ray of dorsal fin is comparatively strong, smooth and osseous. Caudal din is deeply forked. Dorsal side is dark grey in colour. Dorsal, pectoral and anal fins are reddish in colour. As there was no any marked morphometric difference in male and female sexes, the detailed morphometric and meristic characters were studied in both the 
sexes together. Five size groups were formed to interpret these characters. Morphometric characters of Tor tor are summarized in Table 1. The minimum sample size of fish is 5 was considered in size group $35-40 \mathrm{~cm}$ and maximum 9 in the size group $25-30 \mathrm{~cm}$. Regression analysis of various body parameters with total length, standard length and head length were calculated and statistical values of intercept (a), regression coefficient (b), coefficient of correlation ( $r$ ) and coefficient of determination ( $\mathrm{r} 2)$ are presented in Table 5, 6, 7 respectively.

Statistics regarding how body parameters grow in ratio of total length is presented in Table 2. The ratio of total length and standard length fluctuated in between $1.2 \pm 0.02: 1$ in size group 35 to $40 \mathrm{~cm}$ to a maximum of $1.23 \pm$ $0.04: 1$ in the size group of 20 to $25 \mathrm{~cm}$. Ratio of total length and head length fluctuated from $5.86 \pm 0.3: 1$ in the length group of 25 to 30 $\mathrm{cm}$ to a maximum of $6.38 \pm 0.71: 1$ in the length group of 20 to $25 \mathrm{~cm}$. Ratio of total length to pre dorsal length was minimum 2.55 $\pm 0.07: 1$ in the size group 20 to $25 \mathrm{~cm}$ and maximum $2.61 \pm 0.13: 1$ in the size group35 to $40 \mathrm{~cm}$. Ratio of total length to pre pectoral length was minimum $4.77 \pm 0.18: 1$ in the size group 20 to $25 \mathrm{~cm}$ and maximum $5.53 \pm$ $0.33: 1$ in the size group 35 to $40 \mathrm{~cm}$. Ratio of total length to pre pelvic length was minimum $2.41 \pm 0.12: 1$ in the size group 30 to $35 \mathrm{~cm}$ and maximum $2.56 \pm 0.35: 1$ in the size group 35 to $40 \mathrm{~cm}$. Ratio of total length to pre anal length was minimum $1.56 \pm 0.15: 1$ in the size group 20 to $25 \mathrm{~cm}$ and maximum $1.78 \pm 0.1: 1$ in the size group 35 to $40 \mathrm{~cm}$. Ratio of total length to eye diameter was minimum $24.99 \pm$ 2.49:1 in the size group 20 to $25 \mathrm{~cm}$ and maximum $36 \pm 0.96$ in the size group 35 to 40 $\mathrm{cm}$.Ratio of total length to snout length was minimum $20.6 \pm 2.42: 1$ in the size group 30 to $35 \mathrm{~cm}$ and maximum $27.28 \pm 5.21: 1$ in the size group 35 to $40 \mathrm{~cm}$. Ratio of total length to maximum body depth was minimum $4.98 \pm$ $0.32: 1$ in the size group 20 to $25 \mathrm{~cm}$ and maximum $5.52 \pm 0.22: 1$ in the size group 35 to $40 \mathrm{~cm}$. Ratio of total length to caudal length was minimum $5.13 \pm 0.09: 1$ in the size group 20 to $25 \mathrm{~cm}$ and maximum $5.36 \pm 0.2: 1$ in the size group 35 to $40 \mathrm{~cm}$.

Body parameters in ratio of standard length were calculated and presented in Table 3 . The ratio of standard length and head length fluctuated from a minimum $4.77 \pm 0.22: 1$ in the size group of 25 to $30 \mathrm{~cm}$ to a maximum of $5.24 \pm 0.34: 1$ in the size group of 35 to 40 $\mathrm{cm}$. Ratio of standard length to pre dorsal length was minimum 2.08+_0.03:1in the size group of 25 to $30 \mathrm{~cm}$ and maximum $2.17 \pm$ $0.26: 1$ in the size group 35 to $40 \mathrm{~cm}$. Ratio of standard length to pre pectoral length was minimum $3.89 \pm 0.15: 1$ in the size group 20 to $25 \mathrm{~cm}$. and maximum $4.59 \pm 0.28: 1$ in the size group 35 to $40 \mathrm{~cm}$. Ratio of standard length to pre pelvic length was minimum2.01 $\pm 0.14: 1$ in the size group 30 to $35 \mathrm{~cm}$ and maximum $2.13 \pm 0.29: 1$ in the size group 35 to $40 \mathrm{~cm}$. Ratio of standard length to pre anal length was minimum $1.27 \pm 0.14: 1$ in a length group 
20 to $25 \mathrm{~cm}$ and maximum $1.48 \pm 0.09: 1$ in the length group 35 to $40 \mathrm{~cm}$. Ratio of standard length to eye diameter was minimum $20.39 \pm$ 1.78:1 in the size group 20 to $25 \mathrm{~cm}$ and maximum $30.4 \pm 1.14: 1$ in the size group 35 to $40 \mathrm{~cm}$. Ratio of standard length to snout length was minimum $17.22 \pm 2.32: 1$ in the size group 30 to $35 \mathrm{~cm}$ and maximum $22.65 \pm$ $4.31: 1$ in the size group 35 to $40 \mathrm{~cm}$. Ratio of standard length to maximum body depth was minimum $4.07 \pm 0.3: 1$ in the size group 21 to $25 \mathrm{~cm}$ and maximum $4.58 \pm 0.21: 1$ in the size group 35 to $40 \mathrm{~cm}$. Ratio of standard length to caudal length was minimum $4.09 \pm 0.17: 1$ in the size group 25 to $30 \mathrm{~cm}$ and maximum 4.45 $\pm 0.13: 1$ in the size group 35 to $40 \mathrm{~cm}$.

Body parameters in ratio of head length were calculated and presented in Table 4. The ratio of head length to eye diameter fluctuated from minimum $3.98 \pm 0.7: 1$ in the size group of 20 to $25 \mathrm{~cm}$ and maximum of $5.82 \pm 0.4: 1$ in a length group of 35 to $40 \mathrm{~cm}$. The ratio of head length to snout length was minimum $3.37 \pm$ 0.49:1 in size group 30 to $35 \mathrm{~cm}$ and maximum $4.34 \pm 0.87: 1$ in the size group 35 to $40 \mathrm{~cm}$. The ratio of head length to maximum body depth was minimum $0.79 \pm 0.1: 1$ in the size group 20 to $25 \mathrm{~cm}$ and maximum $0.88 \pm$ 0.03:1 in the size group 35 to $40 \mathrm{~cm}$.

Data on modelling based on regression analysis is presented in the Table 5 (Total length as independent parameter), Table 6 (Standard length as independent variable) and Table 7 (Head length as independent parameter). Different models and allied statistical parameters are as follows:

1. Standard length $=-0.99+0.86 \quad$ Total length Correlation coefficient $(\mathrm{r})=0.98$,

Coefficient of determination $(\mathrm{r} 2)=0.95$

2. Head length $=0.12+0.16$ Total length Correlation coefficient $(r)=0.92$

Coefficient of determination $(\mathrm{r} 2)=0.84$

3. Pre dorsal length $=0.39+0.38$ Total length

Correlation coefficient $(r)=0.94$

Coefficient of determination $(\mathrm{r} 2)=0.88$

4. Pre pectoral length $=1.79+0.13$ Total length

Correlation coefficient $(r)=0.93$

Coefficient of determination $(\mathrm{r} 2)=0.86$

5. Pre pelvic length $=0.61+0.39$ Total length

Correlation coefficient $(r)=0.87$

Coefficient of determination $(\mathrm{r} 2)=0.75$

6. Pre anal length $=5.42+0.42$ Total length

Correlation coefficient $(r)=0.88$

Coefficient of determination $(\mathrm{r} 2)=0.77$

7. Eye diameter $=0.79+0.01$ Total length

Correlation coefficient $(r)=0.32$

Coefficient of determination $(\mathrm{r} 2)=0.10$

8. Snout length $=0.37+0.03$ Total length

Correlation coefficient $(r)=0.55$

Coefficient of determination $(\mathrm{r} 2)=0.30$

9. Max. body depth $=1.46+0.14$ Total length

Coefficient of correlation $(r)=0.90$

Coefficient of determination $(\mathrm{r} 2)=0.81$

10. Caudal length $=0.64+0.17$ Total length

Coefficient of correlation $(r)=0.98$

Coefficient of determination $(\mathrm{r} 2)=0.96$.

11. Head length $=0.6+0.17$ Standard length

Coefficient of correlation $(r)=0.8769$

Coefficient of determination $(\mathrm{r} 2)=0.769$

12. Pre Dorsal length $=1.3577+0.4167$

Standard length 
Coefficient of correlation $(r)=0.9148$

Coefficient of determination $(\mathrm{r} 2)=0.83$

13. Pre pectoral length $=2.0626+0.149$

Standard length

Correlation coefficient $(r)=0.9224$

Coefficient of determination $(\mathrm{r} 2)=0.85$

14. Pre pelvic length $=1.3324+0.4402$ Standard length

Correlation coefficient $(r)=0.8669$

Coefficient of determination $(\mathrm{r} 2)=0.752$

15. Pre anal length $=6.783+0.4536$ Standard length

Correlation coefficient $(r)=0.833$

Coefficient of determination $(\mathrm{r} 2)=0.694$.

16. Eye diameter $=0.7874+0.007$ Standard length

Correlation coefficient $(\mathrm{r})=0.3564$

Coefficient of determination $(\mathrm{r} 2)=0.127$

17. Snout length $=0.3957+0.0388$ Standard length

Correlation coefficient $(\mathrm{r})=0.5746$
Coefficient of determination $(\mathrm{r} 2)=0.33$

18. Maximum body depth $=1.881+0.1565$

Standard length

Coefficient of correlation $(r)=0.8633$

Coefficient of determination $(\mathrm{r} 2)=0.74$

19. Caudal length $=1.03+0.19$ Standard length Coefficient of correlation $(r)=0.96$

Coefficient of determination $(\mathrm{r} 2)=0.92$.

20. Eye diameter $=0.844+0.0234$ Head length

Correlation coefficient $(r)=0.2356$

Coefficient of determination $(\mathrm{r} 2)=0.056$

21. Snout length $=0.4431+0.1855$ Head length

Correlation coefficient $(\mathrm{r})=0.5441$

Coefficient of determination $(\mathrm{r} 2)=0.296$

22. Maximum body depth $=1.575+0.8532$

Head length

Coefficient of correlation $(r)=0.9315$

Coefficient of determination $(\mathrm{r} 2)=0.868$

\section{Table 1: Summarized Data on the Mophometrics of Tor tor}

\begin{tabular}{|c|c|c|c|c|c|c|c|c|c|c|c|c|c|}
\hline $\begin{array}{l}\text { S. } \\
\text { No. }\end{array}$ & $\begin{array}{l}\text { Size } \\
\text { Gps } \\
\text { (cm) }\end{array}$ & TL & ST & HL & PDL & PPL & PVL & PAL & ED & Sn. L & MBD & $\begin{array}{ll}\mathbf{C L} & \mathbf{0} \\
\mathbf{0} & \mathbf{f}\end{array}$ & $\begin{array}{l}\text { No. } \\
\text { of } \\
\text { fish }\end{array}$ \\
\hline 1 & $20-25$ & $\begin{array}{c}23.59 \\
\pm 1.0 \\
1\end{array}$ & $\begin{array}{c}19.26 \pm 0 \\
.83\end{array}$ & $\begin{array}{c}3.75 \pm 0 \\
53\end{array}$ & $\begin{array}{c}9.25 \pm 0 . \\
44\end{array}$ & $\begin{array}{c}4.95 \pm 0 . \\
09\end{array}$ & $\begin{array}{c}9.64 \pm 1 . \\
01\end{array}$ & $\begin{array}{c}15.33 \pm 1 \\
.99\end{array}$ & $\begin{array}{c}0.95 \pm 0 \\
08\end{array}$ & $\begin{array}{c}1.11 \pm 0 . \\
21\end{array}$ & $\begin{array}{c}4.75 \pm 0 \\
33\end{array}$ & $\begin{array}{c}.4 .6 \pm 0 \\
.24\end{array}$ & 8 \\
\hline 2 & $25-30$ & $\begin{array}{c}27.96 \\
\pm 1.6 \\
7\end{array}$ & $\begin{array}{c}22.79 \pm 1 \\
.59\end{array}$ & $\begin{array}{c}4.78 \pm 0 \\
25\end{array}$ & $\begin{array}{c}10.94 \pm 0 \\
.77\end{array}$ & $\begin{array}{c}5.41 \pm 0 . \\
36\end{array}$ & $\begin{array}{c}11.43 \pm 0 \\
.65\end{array}$ & $\begin{array}{c}17.2 \pm 0 \\
93\end{array}$ & $\begin{array}{c}0.91 \pm 0 \\
12\end{array}$ & $\begin{array}{c}1.29 \pm 0 . \\
28\end{array}$ & $\begin{array}{c}5.6 \pm 0.4 \\
3\end{array}$ & $\begin{array}{c}5.58 \pm \\
0.3\end{array}$ & 9 \\
\hline 3 & $30-35$ & $\begin{array}{c}32.1 \\
\pm 1.2 \\
5\end{array}$ & $\begin{array}{c}26.81 \pm 1 \\
.33\end{array}$ & $\begin{array}{c}5.24 \pm 0 . \\
37\end{array}$ & $\begin{array}{c}12.49 \pm 0 \\
.82\end{array}$ & $\begin{array}{c}6.09 \pm 0 . \\
27\end{array}$ & $\begin{array}{c}13.36 \pm 0 \\
.92\end{array}$ & $\begin{array}{c}19.04 \pm 0 \\
.89\end{array}$ & $\begin{array}{c}0.99 \pm 0 \\
04\end{array}$ & $\begin{array}{c}1.58 \pm 0 . \\
17\end{array}$ & $\begin{array}{c}6.05 \pm 0 \\
43\end{array}$ & $\begin{array}{c}6.18 \pm \\
0.1\end{array}$ & 8 \\
\hline 4 & $35-40$ & $\begin{array}{c}36.6 \\
\pm 0.9 \\
6\end{array}$ & $\begin{array}{c}30.4 \pm 1 \\
14\end{array}$ & $\begin{array}{c}5.82 \pm 0 \\
4\end{array}$ & $\begin{array}{c}14.14 \pm 1 \\
.38\end{array}$ & $\begin{array}{c}6.64 \pm 0 . \\
42\end{array}$ & $\begin{array}{c}14.5 \pm 2 \\
21\end{array}$ & $\begin{array}{c}20.6 \pm 1 \\
14\end{array}$ & $1 \pm 0$ & $\begin{array}{c}1.38 \pm 0 \\
26\end{array}$ & $\begin{array}{c}6.64 \pm 0 \\
27\end{array}$ & $\begin{array}{c}6.84 \pm \\
0.44\end{array}$ & 5 \\
\hline
\end{tabular}


Table 2: Growth of Total Length in Ratio of Different Body Parts of Tor tor

\begin{tabular}{|c|c|c|c|c|c|c|c|c|c|c|c|}
\hline $\begin{array}{c}\text { S.No } \\
\text { · }\end{array}$ & $\begin{array}{l}\text { Size } \\
\text { Groups } \\
\text { (cm) }\end{array}$ & ST & HL & PDL & PPL & PVL & PAL & ED & Sn. L & MBD & CL \\
\hline 1 & $20-25$ & $\begin{array}{c}1.23 \pm \\
0.04\end{array}$ & $\begin{array}{c}6.38 \pm 0 . \\
71\end{array}$ & $\begin{array}{c}2.55 \pm 0 \\
07\end{array}$ & $\begin{array}{c}4.77 \pm 0 . \\
18\end{array}$ & $\begin{array}{c}2.46 \pm 0 . \\
18\end{array}$ & $\begin{array}{c}1.56 \pm 0 . \\
15\end{array}$ & $\begin{array}{c}24.99 \pm 2 \\
49\end{array}$ & $\begin{array}{c}21.69 \pm 3 . \\
06\end{array}$ & $\begin{array}{c}4.98 \pm 0 . \\
32\end{array}$ & $\begin{array}{c}5.13 \pm 0 \\
09\end{array}$ \\
\hline 2 & $25-30$ & $\begin{array}{l}1.23 \pm \\
0.03\end{array}$ & $\begin{array}{c}5.86 \pm 0 . \\
3\end{array}$ & $\begin{array}{c}2.56 \pm 0 \\
09\end{array}$ & $\begin{array}{c}5.18 \pm 0 . \\
34\end{array}$ & $\begin{array}{c}2.45 \pm 0 . \\
19\end{array}$ & $\begin{array}{c}1.63 \pm 0 . \\
05\end{array}$ & $\begin{array}{c}31.12 \pm 4 \\
17\end{array}$ & $\begin{array}{c}22.46 \pm 4 \\
28\end{array}$ & $\begin{array}{l}5.01 \pm 0 . \\
39\end{array}$ & $\begin{array}{c}5.01 \pm 0 \\
1\end{array}$ \\
\hline 3 & $30-35$ & $\begin{array}{c}1.2 \pm 0 \\
06\end{array}$ & $\begin{array}{c}6.14 \pm 0 . \\
28\end{array}$ & $\begin{array}{c}2.57 \pm 0 \\
09\end{array}$ & $\begin{array}{c}5.28 \pm 0 . \\
15\end{array}$ & $\begin{array}{c}2.41 \pm 0 . \\
12\end{array}$ & $\begin{array}{c}1.69 \pm 0 . \\
08\end{array}$ & $\begin{array}{c}32.53 \pm 1 \\
4\end{array}$ & $\begin{array}{c}20.6 \pm 2.4 \\
2\end{array}$ & $\begin{array}{c}5.32 \pm 0 . \\
25\end{array}$ & $\begin{array}{c}5.2 \pm 0.1 \\
3\end{array}$ \\
\hline 4 & $35-40$ & $\begin{array}{c}1.2 \pm 0 \\
02\end{array}$ & $\begin{array}{c}6.31 \pm 0 . \\
4\end{array}$ & $\begin{array}{c}2.61 \pm 0 \\
3\end{array}$ & $\begin{array}{c}5.53 \pm 0 . \\
33\end{array}$ & $\begin{array}{c}2.56 \pm 0 . \\
35\end{array}$ & $\begin{array}{c}1.78 \pm 0 . \\
1\end{array}$ & $\begin{array}{c}36.6 \pm 0.9 \\
6\end{array}$ & $\begin{array}{c}27.28 \pm 5 \\
21\end{array}$ & $\begin{array}{l}5.52 \pm 0 . \\
22\end{array}$ & $\begin{array}{c}5.36 \pm 0 . \\
2\end{array}$ \\
\hline \multicolumn{2}{|c|}{ Average } & $\begin{array}{l}1.22 \pm \\
0.04\end{array}$ & $\begin{array}{c}6.15 \pm 0 . \\
48\end{array}$ & $\begin{array}{c}2.57 \pm 0 \\
13\end{array}$ & $\begin{array}{c}5.15 \pm 0 . \\
36\end{array}$ & $\begin{array}{c}2.46 \pm 0 . \\
2\end{array}$ & $\begin{array}{c}1.65 \pm 0 . \\
12\end{array}$ & $\begin{array}{c}30.77 \pm 4 \\
78\end{array}$ & $\begin{array}{c}22.56 \pm 4 \\
19\end{array}$ & $\begin{array}{c}5.17 \pm 0 . \\
36\end{array}$ & $\begin{array}{c}5.17 \pm 0 . \\
13\end{array}$ \\
\hline
\end{tabular}

Table 3: Growth of Standard Length in Ratio of Different Body Parts of Tor tor

\begin{tabular}{|c|c|c|c|c|c|c|c|c|c|c|}
\hline $\begin{array}{l}\text { S.N } \\
\text { o. }\end{array}$ & $\begin{array}{c}\text { Size } \\
\text { Grou } \\
\text { ps } \\
(\mathbf{c m})\end{array}$ & HL & PDL & PPL & PVL & PAL & ED & Sn. L & MBD & $\mathbf{C L}$ \\
\hline 1 & $20-25$ & $\begin{array}{c}5.22 \pm 0 . \\
7\end{array}$ & $\begin{array}{c}2.08 \pm 0 . \\
07\end{array}$ & $\begin{array}{c}3.89 \pm 0 . \\
15\end{array}$ & $\begin{array}{c}2.01 \pm 0 . \\
15\end{array}$ & $\begin{array}{c}1.27 \pm 0 . \\
14\end{array}$ & $\begin{array}{c}20.39 \pm 1 \\
.78\end{array}$ & $\begin{array}{c}17.71 \pm 2 \\
.46\end{array}$ & $\begin{array}{c}4.07 \pm 0 . \\
3\end{array}$ & $\begin{array}{c}4.19 \pm 0 . \\
15\end{array}$ \\
\hline 2 & $25-30$ & $\begin{array}{c}4.77 \pm 0 . \\
22\end{array}$ & $\begin{array}{c}2.08 \pm 0 . \\
03\end{array}$ & $\begin{array}{c}4.22 \pm 0 . \\
25\end{array}$ & $2 \pm 0.15$ & $\begin{array}{c}1.32 \pm 0 . \\
06\end{array}$ & $\begin{array}{c}25.35 \pm 3 \\
.39\end{array}$ & $\begin{array}{c}18.26 \pm 3 \\
.21\end{array}$ & $\begin{array}{c}4.08 \pm 0 . \\
3\end{array}$ & $\begin{array}{c}4.09 \pm 0 . \\
17\end{array}$ \\
\hline 3 & $30-35$ & $\begin{array}{c}5.14 \pm 0 . \\
43\end{array}$ & $\begin{array}{c}2.15 \pm 0 . \\
16\end{array}$ & $\begin{array}{c}4.41 \pm 0 . \\
25\end{array}$ & $\begin{array}{c}2.01 \pm 0 . \\
14\end{array}$ & $\begin{array}{c}1.41 \pm 0 . \\
12\end{array}$ & $\begin{array}{c}27.16 \pm 1 \\
.14\end{array}$ & $\begin{array}{c}17.22 \pm 2 \\
.32\end{array}$ & $\begin{array}{c}4.45 \pm 0 . \\
36\end{array}$ & $\begin{array}{c}4.34 \pm 0 . \\
2\end{array}$ \\
\hline 4 & $35-40$ & $\begin{array}{c}5.24 \pm 0 . \\
34\end{array}$ & $\begin{array}{c}2.17 \pm 0 . \\
26\end{array}$ & $\begin{array}{c}4.59 \pm 0 . \\
28\end{array}$ & $\begin{array}{c}2.13 \pm 0 . \\
29\end{array}$ & $\begin{array}{c}1.48 \pm 0 . \\
09\end{array}$ & $\begin{array}{c}30.4 \pm 1 \\
14\end{array}$ & $\begin{array}{c}22.65 \pm 4 \\
.31\end{array}$ & $\begin{array}{c}4.58 \pm 0 . \\
21\end{array}$ & $\begin{array}{c}4.45 \pm 0 . \\
13\end{array}$ \\
\hline \multicolumn{2}{|c|}{ Average } & $\begin{array}{c}5.07 \pm 0 . \\
48\end{array}$ & $\begin{array}{c}2.12 \pm 0 . \\
14\end{array}$ & $\begin{array}{c}4.24 \pm 0 . \\
33\end{array}$ & $\begin{array}{c}2.03 \pm 0 . \\
17\end{array}$ & $\begin{array}{c}1.36 \pm 0 \\
13\end{array}$ & $\begin{array}{c}25.35 \pm 4 \\
.07\end{array}$ & $\begin{array}{c}18.56 \pm 3 \\
.43\end{array}$ & $\begin{array}{c}4.26 \pm 0 . \\
36\end{array}$ & $\begin{array}{c}4.27 \pm 0 . \\
16\end{array}$ \\
\hline
\end{tabular}


Table 4: Growth of Head Length in Ratio of Different Body Parts of Tor tor

S.No. Size Groups (cm) Eye-Diameter $\quad$ Snout-Length Maximum Body depth

\begin{tabular}{ccccc}
\hline 1 & $20-25$ & $3.98 \pm 0.7$ & $3.42 \pm 0.52$ & $0.79 \pm 0.1$ \\
2 & $25-30$ & $5.31 \pm 0.63$ & $3.84 \pm 0.72$ & $0.85 \pm 0.03$ \\
3 & $30-35$ & $5.31 \pm 0.44$ & $3.37 \pm 0.49$ & $0.87 \pm 0.03$ \\
4 & $35-40$ & $5.82 \pm 0.4$ & $4.34 \pm 0.87$ & $0.88 \pm 0.03$ \\
& Average & $5.04 \pm 0.87$ & $3.68 \pm 0.71$ & $0.84 \pm 0.07$ \\
\hline
\end{tabular}

Table 5: Regression Analysis and Correlation Coefficient between Total Length and Dependent Parameters of Tor tor

\begin{tabular}{clcccc}
\hline S.No. & Dependent Parameter & $\begin{array}{c}\text { Intercept } \\
(\mathbf{a})\end{array}$ & $\begin{array}{c}\text { Regression } \\
\text { Coefficient } \\
(\mathbf{b})\end{array}$ & $\begin{array}{c}\text { Correlation } \\
\text { Coefficient } \\
(\mathbf{r})\end{array}$ & $\begin{array}{c}\text { Coefficient of } \\
\text { Determination } \\
\left(\mathbf{r}^{2}\right)\end{array}$ \\
\hline 1 & & -0.99 & 0.86 & 0.98 & 0.95 \\
2 & Standard Length & 0.12 & 0.16 & 0.92 & 0.84 \\
3 & Head Length & 0.39 & 0.38 & 0.94 & 0.88 \\
4 & Pre-Dorsal Length & 1.79 & 0.13 & 0.93 & 0.86 \\
5 & Pre-Pectoral Length & 0.61 & 0.39 & 0.87 & 0.75 \\
6 & Pre-Anal Length & 5.42 & 0.42 & 0.88 & 0.77 \\
7 & Eye-Diameter & 0.79 & 0.01 & 0.32 & 0.10 \\
8 & Snout-Length & 0.37 & 0.03 & 0.55 & 0.30 \\
9 & Maximum Body depth & 1.46 & 0.14 & 0.90 & 0.81 \\
10 & Caudal Length & 0.64 & 0.17 & 0.98 & 0.96 \\
\hline
\end{tabular}

Table 6: Regression Analysis and Correlation Coefficient between Standard Length and Dependent Parameters of Tor tor

\begin{tabular}{llcccc}
\hline S.No. & $\begin{array}{l}\text { Dependent } \\
\text { Parameter }\end{array}$ & $\begin{array}{l}\text { Intercept } \\
\text { (a) }\end{array}$ & $\begin{array}{l}\text { Regression } \\
\text { Coefficient (b) }\end{array}$ & $\begin{array}{l}\text { Correlation } \\
\text { Coefficient (r) }\end{array}$ & $\begin{array}{l}\text { Coefficient of } \\
\text { Determination (r) }\end{array}$ \\
\hline 1 & Head length & 0.6 & 0.17 & 0.876931 & 0.769 \\
2 & Pre-Dorsal Length & 1.3577 & 0.4167 & 0.914813 & 0.83 \\
3 & Pre-Pectoral Length & 2.0626 & 0.1493 & 0.922436 & 0.85 \\
4 & Pre-Pelvic Length & 1.3324 & 0.4402 & 0.86694 & 0.752 \\
5 & Pre-Anal Length & 6.783 & 0.4536 & 0.833309 & 0.694 \\
6 & Eye-Diameter & 0.7874 & 0.007 & 0.356498 & 0.127 \\
7 & Snout-Length & 0.3957 & 0.0388 & 0.574644 & 0.33 \\
8 & Max. Body depth & 1.8818 & 0.1565 & 0.863317 & 0.74 \\
9 & Caudal Length & 1.03 & 0.19 & 0.96 & 0.92 \\
\hline
\end{tabular}


Table 7: Regression Analysis and Correlation Coefficient between Head Length and Dependent Parameters of Tor tor

\begin{tabular}{clcccc}
\hline S.No. & $\begin{array}{l}\text { Dependent } \\
\text { Parameter }\end{array}$ & Intercept (a) & $\begin{array}{l}\text { Regression } \\
\text { Coefficient (b) }\end{array}$ & $\begin{array}{l}\text { Correlation } \\
\text { Coefficient (r) }\end{array}$ & $\begin{array}{l}\text { Coefficient of } \\
\left.\text { Determination ( } \mathbf{r}^{2}\right)\end{array}$ \\
\hline 1 & Eye-Diameter & 0.8445 & 0.0234 & 0.235623 & 0.056 \\
2 & $\begin{array}{l}\text { Snout-Length } \\
3\end{array}$ & 0.4431 & 0.1855 & 0.5441 & 0.296 \\
$\begin{array}{l}\text { Maximum Body } \\
\text { depth }\end{array}$ & 1.5715 & 0.8532 & 0.931555 & 0.868 \\
\hline
\end{tabular}

Meristic analysis: During the present studies 5 meristic characters have been counted i.e. Dorsal fin rays, Pectoral fin rays, Pelvic fin rays, Anal fin rays and Caudal fin rays. Meristic characters have definite number and count. The fin formula was summarised as:

D - 12(3/9) Pi -14-16 Pii - 9, A- 7 (2/5) C 19-20. Barbels- 2 pairs.

\section{Results and Discussion}

In the present study, no any remarkable characters of sexual dimorphism were noticed in Tor tor except during breeding season when slight roughness on the belly of male fish was seen whereas there was smoothness on the belly of female. It is a temporary character which is seen especially during breeding season of fish. Secondary sexual characters of many fishes are reported in earlier literature. According to Gunther (1886), in the most teleost, the enlargement and coloration of the belly in adult female loaches is a characteristics feature during the breeding season. Hora (1922) identified sex distinguishing characters in male of Noemacheilus tibetanusas a slit like deep grooves in front of the eye and a kind of padding and thickening with tubercles on the upper surface of pectoral fins as found in most of the cyprinids.

The tubercles as a sexual character were also recorded on the sides of head by Desai (1973) in Tor tor of Narmada River. In Kumaun Tor tor, these tubercles were found spread over the head, while they were absent in Tor putitora of Narmada. According to Pathani (1978), some males were brighter than the females and some males had small black spots on the lateral sides of mouth in Tor tor. The golden colour might be absent in young specimens. Similar characteristics were found in fishes under study in river Ujh (kathua).

During present investigations the correlationship between Total length and external body parts are studied. The most highly correlated body parameter in relation to total length is Standard length $(r=0.98)$ and least correlation with eye diameter $(r=0.32)$ in table 2.5 . The correlation-ship between Standard and external body parts, analysis shows highest correlation with Caudal length $(r=0.96)$ and least correlation with eye diameter $(r=0.35)$ 
in table 2.6 and the correlation-ship between Head length and external body parts shows close relationship with maximum body depth $(r=0.93)$ and least value with eye diameter in table 2.7. The correlation analysis shows that all the morphometric character examined and shows a significant positive correlation which indicates isometric growth in all the organs of Tor tor under natural conditions. Singh and Dobriyal (1983) studied the morphometric characters and their relationships in the hillstream cat fish Pseudecheneis sulcatus (McClelland) collected in the river Alaknanda at Srinagar and found no second stock. According to Dobriyal and Bahuguna (1987), there was no significant difference in the stock of population of $N$. montanus collected from Khanda stream. Dobriyal et al. (1988) also reported single stock in Noemacheilus denisonii and Noemacheilus multifaciatus from the same stream. Uniyal et al. (2005) also studied the morphometric characters and their relationship in the fish Tor chilinoides at Western Nayar and found no any second stock. Bahuguna (2007) concluded that there was a single stock of the population of Puntius conchonius (Ham-Buch) in river Mandal. The diagnostic features shows that Tor tor is deep bodied Mahseer having head is smaller than body depth. Mouth is small with two pair of barbels. Dorsal fin is opposite to ventral fin. Caudal fin deeply forked with caudal peduncle. It is caudal, pelvic and anal fins show tint of reddish golden colour while the body above its lateral line is generally golden in colour in adulthoods. Lateral line is complete. During present studies meristic counts were counted like dorsal spine or rays 12 in numbers, pectoral rays are14-16 in numbers, pelvic fin rays are 9 in numbers, anal fin rays 7 in numbers, caudal rays are 19-20 in number, 2 pairs of barbells are present, Scales above lateral line are 4-5, Scales below lateral line are 4-5 in numbers. All the meristic characters are almost constant in all the length groups of fish with different body length which is similar to the studies carried out by Zafar et al. (2012) and Rahman (1989).

The morphometric and meristic characters shows linear regression relationship and confirmed that the test specimen is Tor tor and there is single stock of population. These results will be beneficial for fishery research, taxonomy and for management and conservation of fish.

\section{References}

Bahuguna PK, Joshi HK, Dobriyal AK (2007). Fecundity and sex ratio in Puntius conchonius (Pisces; Cyprinidae) from Garhwal Himalaya, Environmental conservation Journal 8(1-2): 37-43

Desai VR (1973). Studies on Fishery of Tor tor (Ham.) from river Narbada. Proc. Indian. Nat.Sci. Acad. 39 (2b): 228-248.

Dobriyal AK, Bahuguna AK (1987). Morphometric character and their relationships in the hillstream loach 
Noemacheilus montanus. Him. J. Env.

Zool, 1: 23-27.

Dobriyal AK, Bahuguna AK, Singh HR (1988). Morphometric characters and their relationship in two Noemacheilus species from Garhwal Himalaya. Agra.

Boil. Res. 4(2): 21-24.

Gunther A (1886). Hand-buch deer Ichthyologie, Wien.

Hora SL (1922). On fishes belonging to the family cobitidae from high altitudes in central Asia. Rec. Ind. Mus., 24: 63-83.

Jain Sharad K, Agarwal Pushpendra K, Singh Vijay P (2007). Hydrology and Water Resources of India, Springer Science and Business Media, p. 482, ISBN 9781-4020-5180-7.

Joshi P C (1994). Ecological restoration of water and fish population in the Himalayan Rivers of U.P. J. Freshwater Biol., 6(2): 101-107.

Langer S, Tripathi NK, Khajuria B (2013). Morphometric and meristic study of Golden Mahseer (Tor putitora) from Jhajjar stream (J\&K), India. Res. J. Animal, Veterinary and Fishery Sci., 1(7): 1-4.

Nikolsky GV (1961). The causes of fluctuations in fish numbers. Vopr. Ikhtiol. 1:4

Pathani SS (1978). A note on secondary sexual characters in Kumaun mahseer Tor tor (Ham.) and Tor putitora (Ham.) in Uttar
Pradesh. Indian J. Anim. Sci. 48(10): 773-775.

Rahman A K A (1989). Fresh water fishes of Bangladesh. Zoological Society of Bangladesh. Department of Zoology University of Dhaka.

Rathore V, Dutta S P S (2015). Fish fauna of river Ujh, an important tributary of the river Ravi, District Kathua, Jammu. Environment Conservation Journal, 16: 81- 86.

Singh H.R, Dobriyal, A.K. (1983). Morphometric characters and their relationships in the catfish Pseudecheneis sulcatus. Indian J. Anim. Sci. 53: 541-546.

Uniyal SP, Dobriyal AK, Bisht MS, Joshi H.K. (2005b). Morphometric and meristic analysis of Tor chelynoides (Pisces: cyprinidae) from the river Western Nayar of Garhwal, Central Himalaya. Panjab UnivRes. J. (Sci), Vol. 55: 63-67.

Zafar Muhammad, Nazir A, Akhtar N, Naquei SMHM, Rehman M (2012). Studies on Meristic counts and Morphometric measurements of Mahseer (Tor putitora) from a spawning ground of Himalayan fool-hill river Korang Islamabad, Pakistan. Pak. J. Bio. Sci. 5(6): 733-735. 